\title{
A Note on the Water Movements in the English Channel and Neighbouring Seas, considered on the basis of Salinity Distribution.
}

\author{
By \\ J. R. Lumby, \\ Fisheries Laboratory, Lowestoft.
}

COMParison of the conceptions which have hitherto been held in regard to the hydrography of the English Channel with those which are offered as a result of the recent activities of the Atlantic Slope Committee, shows that a difference exists which, in the writer's opinion, lies in the interpretation of the material, rather than in the fundamental differences in the material itself. For example, it is stated that the physical character of the water in the English Channel is conditioned, especially in the summer months, by that of the North Sea water rather than by that of the Atlantic water. "En plein été, en août, les eaux chaudes de la mer du Nord affluent dans la Manche."* A similar regimen is suggested for the waters of the Irish Sea, which are said to be derived from the northward. Carruthers shows $\uparrow$ that the normal water movement in the eastern part of the English Channel is through Dover Straits into the Southern Bight, this movement appearing to be more persistent along the bottom than on the surface. Furthermore, one of the two months in which reversal of this direction appears least likely to occur is August.

In a recent papert in which the writer discusses the salinity of the English Channel during the period 1920-23, it is shown that during the summer months of 1921 and 1922, water of unusually high salinity was present in the eastern basin of the Channel. The salinity is sufficient evidence that this water cannot have come from the North Sea, and it must, therefore, have come from the Atlantic. But since this water of high salinity apparently did not cross the line Isle of Wight-Cape de la Hague on the surface at any time previous to its appearance in the eastern basin, it follows that it entered the Channel as a subsurface

\footnotetext{
* Ed. le Danois, Rapport Atlantique; 1921. Cons. Perm. Int. pour l'Explor. de la Mer. $\dagger$ J. N. Carruthers, vide p. 665 of this volume.

¥ Min. of Agric. and Fish. Fish Invest., Ser. II, Vol. VII, No: 7, 1924.
} 
layer, below the discontinuity layer for the most part, and appeared at the surface in the eastern basin, where the depth is small and where the vertical mixing effects of the winds and tides are consequently felt throughout the whole water column. So far as the surface of the Channel as a whole is concerned, there appear to be two distinct types of salinity distribution, which may be assigned broadly to winter and summer. In winter the isohalines are approximately parallel to the land, converging towards the east, and the salinity decreases regularly from the Atlantic in the west to the Southern Bight in the east. The winter distribution may be interpreted as showing a movement of ocean water in an easterly direction throughout the length of the Channel.

The most striking differences between winter and summer distributions are two in number. Firstly, in summer, a patch of relatively salt water occurs in the eastern basin. Secondly, oft the western entrance to the Channel the isohalines which run east and west in winter, become convex towards the south. It is the interpretation of this latter phenomenon which has given rise to the inconsistency felt by the writer to exist between the older and newer conceptions of the hydrographical regimen of the Channel.

The idea underlying the conclusions reached by Le Danois appears to be the conflict of the water of low salinity in the Irish Sea and off the Bristol Channel with the salter ocean water from the south. In summer, while the salter water has a northerly tendency, the fresh water moves bodily to the southward across the mouth of the English Channel. But the circulatory system which Matthews* suggested on the evidence of salinity and temperature distribution for these waters is at least equally applicable, and if the water movements are considered on these grounds, it then becomes possible to co-ordinate the conclusions as to water movements arrived at from considerations other than salinity or temperature distribution.

Matthews showed that for the sea south of Ireland the water movement was anti-clockwise, and that relatively salt water coming from the direction of Land's End moved through St. George's Channel into the lrish Sea. It is only necessary to draw attention to the following statement made by him, in order to make the difference clear, viz. "One way of drawing the isohalines, which would fit the mean results perfectly, has not been followed as it would necessitate the assumption of a strong current of low salinity flowing from St. George's Channel to far south of $50^{\circ}$ N. Lat. Such a current would be inherently improbable, and there is no reason to suppose that it exists when there is a much simpler explanation to hand." (The italics are the writer's.)

At times this anti-clockwise circulation was found to extend as far

* D. J. Matthews, Fisheries, Ireland, Sci. Invest., 1913, IV (1914). 
south as $48 \frac{1}{2}^{\circ} \mathrm{N}$. Lat., and the monthly charts of surface salinity prepared by the writer for the period 1920-23 show that in the summers of 1921 and 1922 this fresher water system reached at least as far south as Ushant. Furthermore, it was possible to account for the salinity distributions found during this period in the English Channel on the grounds of the circulation suggested by the earlier investigations, whereas, if the system suggested by Le Danois is assumed, it becomes difficult to account both for the presence and persistence of the relatively salt water patch in the eastern basin of the English Channel, and for the striking divergences which occur, more particularly in summer, between the salinity at the Seven Stones Lightship and that at positions closer inshore.

It may be recalled that Gough's* observations of the drift of Muggicea atlantica Cunn. suggest the entry of water from the Bay of Biscay into the English Channel in the summer of 1904, and Bygrave $†$ states that ". . . a shoal of Limacina retroversa entered the English Channel in 1905, between May and August, and that its distribution in August appears to indicate that it came from the south-west, passing close to Ushant."

Although, for these reasons, it cannot be admitted that the English Channel is entirely cut off from the Atlantic Ocean in the summer months, it is evident, nevertheless, that the extension and retraction of the cyclonic circulation south of Ireland plays an important part in determining seasonal changes in the direction taken by ocean water entering the English Channel.

* L. H. Gough, Publ. de Circ., No. 29, 1905.

$\dagger$ W. Bygrave, N. Sea Fish. Invest., 3rd report (Southern Area), 1906-1908. Cd. 5546,1911 . 